\title{
Nitrogen and phosphorus fertilization of sunflower crop in alkaline Cambisol
}

\author{
Daniely F. Braga ${ }^{1}$, Fabio H. T. de Oliveira ${ }^{2}$, Hemmannuella C. Santos ${ }^{3}$, \\ Adelson P. Araújo ${ }^{4} \&$ Everaldo Zonta ${ }^{4}$ \\ ${ }^{1}$ Universidade Federal Rural do Semi-Árido/Centro Multidisciplinar de Caraúbas/Departamento de Ciência e Tecnologia. Mossoró, RN. E-mail: \\ danielyformiga@ufersa.edu.br \\ ${ }^{2}$ Universidade Federal Rural do Semi-Árido/Centro de Ciências Agrárias/Departamento de Ciências Agronômicas e Florestais. Mossoró, RN. E-mail: \\ fabio@ufersa.edu.br \\ ${ }^{3}$ Instituto Federal de Educação, Ciência e Tecnologia de Pernambuco/Campus Vitória de Santo Antão/Departamento de Assuntos Educacionais. Vitória \\ de Santo Antão, PE. E-mail: hecosantos@vitoria.ifpe.edu.br (Corresponding author) \\ ${ }^{4}$ Universidade Federal Rural do Rio de Janeiro/Instituto de Agronomia/Departamento de Solos. Seropédica, RJ. E-mail: aparaujo@ufrrj.br; ezonta@ufrrj.br
}

Key words:

Helianthus annuus

oilseed crop

nitrogen

phosphorus

\begin{abstract}
A B S T R A C T
Sunflower is a crop that has aroused the interest of farmers because of its adaptability to wide climatic conditions and for its use in biodiesel production. However, there are only a few studies on sunflower fertilization in alkaline soils. This study aimed to evaluate nitrogen $(\mathrm{N})$ and phosphorus (P) fertilization in sunflower (Helianthus annuus L.) cultivated in alkaline soil. A field experiment was carried out in Baraúnas-RN, Brazil, in a Haplic Cambisol derived from calcareous rock, where the sunflower $\mathrm{H}-251$ hybrid was cultivated. The treatments were a combination of four doses of $\mathrm{N}\left(30,60,90\right.$ and $\left.120 \mathrm{~kg} \mathrm{ha}^{-1}\right)$ and four doses of $\mathrm{P}_{2} \mathrm{O}_{5}$ $\left(30,60,90\right.$ and $\left.120 \mathrm{~kg} \mathrm{ha}^{-1}\right)$. Sunflower growth and yield increased with the doses of $\mathrm{N}$ and $\mathrm{P}_{2} \mathrm{O}_{5}$. Doses of $30 \mathrm{~kg} \mathrm{ha}^{-1}$ of $\mathrm{N}$ and $30 \mathrm{~kg} \mathrm{ha}^{-1}$ of $\mathrm{P}_{2} \mathrm{O}_{5}$ were more economical, corresponding to grain yield of $2378 \mathrm{~kg} \mathrm{ha}^{-1}$. Critical levels associated with these doses of $\mathrm{N}$ and $\mathrm{P}_{2} \mathrm{O}_{5}$ were $28.2 \mathrm{~g} \mathrm{~kg}^{-1}$ for $\mathrm{N}$ leaf content, 2.84 for $\mathrm{P}$ leaf content, and $6.75 \mathrm{mg} \mathrm{dm}^{-3}$ for soil available $\mathrm{P}$ extracted by Mehlich-1.
\end{abstract}

\section{Palavras-chave:}

Helianthus annuus oleaginosa nitrogênio fósforo

\section{Adubação nitrogenada e fosfatada na cultura do girassol em Cambissolo alcalino}

\section{R E S U M O}

O girassol é uma cultura que tem despertado o interesse dos produtores por sua adaptabilidade a diferentes condições climáticas e pela possibilidade de produção de biodiesel. Porém, pesquisas sobre adubação de girassol em solos alcalinos são escassas. Neste trabalho, objetivou-se avaliar a resposta da cultura do girassol (Helianthus annuus L.) à adubação nitrogenada e fosfatada em solo alcalino. O experimento de campo foi conduzido no município de Baraúnas, RN, em um Cambissolo Háplico eutrófico, onde se plantou o híbrido de girassol $\mathrm{H}$-251. Os tratamentos resultaram da combinação de quatro doses de $\mathrm{N}\left(30,60,90\right.$ e $\left.120 \mathrm{~kg} \mathrm{ha}^{-1}\right)$ e quatro doses de $\mathrm{P}_{2} \mathrm{O}_{5}\left(30,60,90\right.$ e $\left.120 \mathrm{~kg} \mathrm{ha}^{-1}\right)$. O crescimento e a produtividade do girassol aumentaram com o incremento das doses de $\mathrm{N}$ e de $\mathrm{P}_{2} \mathrm{O}_{5}$. As doses de $30 \mathrm{~kg} \mathrm{ha}^{-1}$ de $\mathrm{N}$ e $30 \mathrm{~kg} \mathrm{ha}^{-1}$ de $\mathrm{P}_{2} \mathrm{O}_{5}$ se mostraram mais econômicas, correspondendo à produtividade de $2.378 \mathrm{~kg} \mathrm{ha}^{-1}$ de grãos. Os níveis críticos associados a essas doses econômicas de $\mathrm{N}$ e de $\mathrm{P}_{2} \mathrm{O}_{5}$ foram $28,2 \mathrm{~g} \mathrm{~kg}^{-1}$ para o teor de $\mathrm{N}$ na folha, $2,84 \mathrm{~g} \mathrm{~kg}^{-1}$ para o teor de $\mathrm{P}$ na folha, e $6,75 \mathrm{mg} \mathrm{dm}^{-3}$ para o $\mathrm{P}$ disponível no solo pelo extrator Mehlich-1. 


\section{INTRODUCTION}

Sunflower (Helianthus annuus L.) has high potential for cultivation in Northeast Brazil because of its easy adaptation, great agro-energetic potential, easy management and good economic performance. In the 2014/2015 season, sunflower production (grains) in Brazil reached 153 thousand tons, with mean yield of $1,374 \mathrm{~kg} \mathrm{ha}^{-1}(\mathrm{CONAB}, 2016)$. In the Northeast region of Brazil, sunflower is still not much cultivated and, when cultivated, low yields are obtained because of the low technological level used by farmers.

At the Apodi Plateau, there is a predominance of soils derived from limestone of the Jandaíra Formation, which in some areas is covered by more recent sandy sediments from the Barreiras Group (Mota et al., 2007). Alkaline Cambisols in Brazil, in general, exhibit very low contents of available phosphorus, micronutrients and organic matter, requiring fertilizations for adequate crop development (Lemos et al., 1997). In the sunflower crop, $\mathrm{N}$ is a crucial element for seed and oil production (Alves et al., 2016), and P is directly related to seed production and quality (Silva et al., 2011).

Hence, the practice of $\mathrm{N}$ and $\mathrm{P}$ fertilization becomes indispensable for crops to obtain high yields in these alkaline soils. Studies on fertilization in the country recommend for the sunflower crop $\mathrm{N}$ doses from 25 to $100 \mathrm{~kg} \mathrm{ha}^{-1}$ and $\mathrm{P}_{2} \mathrm{O}_{5}$ doses from 0 to $110 \mathrm{~kg} \mathrm{ha}^{-1}$ (CFSEMG, 1999; SBCS, 2004; Leite et al., 2007; Bezerra et al, 2014; Campos et al., 2015).

Considering the increasing importance of sunflower in the Brazilian semi-arid region and the lack of research on its fertilization in alkaline soils of the northeast region, this study aimed to evaluate the response of sunflower to nitrogen and phosphate fertilizations in alkaline soil at the Apodi Plateau, RN, Brazil.

\section{Material ANd Methods}

The experimental area is located in the municipality of Baraúnas-RN, Brazil (504’ 48” S; $37^{\circ} 37^{\prime} 00^{\prime \prime}$ W; 94 m). The soil of the area is an alkaline eutrophic Haplic Cambisol, with clay texture, derived from limestone of the Jandaíra Formation, little developed and with a small difference between horizons (Mota et al., 2007).

Before conducting the field experiment, a soil sample was collected in the 0-20 cm layer for chemical and physical characterization (EMBRAPA, 1997), and its characteristics are: $\mathrm{pH}$ (water) $=7.4 ; \mathrm{P}=1.8$ and $\mathrm{K}=210.3 \mathrm{mg} \mathrm{dm}^{-3} ; \mathrm{Ca}^{2+}=4.8$; $\mathrm{Mg}^{2+}=1.3 ; \mathrm{Al}^{3+}=0.0 ;(\mathrm{H}+\mathrm{Al})=1.98 ; \mathrm{Na}^{+}=11.5 \mathrm{cmol}_{\mathrm{c}} \mathrm{dm}^{-3} ;$ Sand $=176.6$; Silt $=330.9$ and Clay $=492.5 \mathrm{~g} \mathrm{~kg}^{-1}$.

The area was subjected to double cross-subsoiling at $40 \mathrm{~cm}$ depth and double cross-harrowing at $20 \mathrm{~cm}$ depth. Each plot had four 6-m-long rows spaced by $0.90 \mathrm{~m}$ and the two central rows were used for evaluation, disregarding $0.5 \mathrm{~m}$ on each end. The H-251 sunflower hybrid, which is small, with short cycle and high yield, was planted at spacing of $0.90 \times 0.30 \mathrm{~m}$.

The experimental design was randomized blocks with four replicates and treatments resulted from the combination of four $\mathrm{N}$ doses $\left(30,60,90\right.$ and $\left.120 \mathrm{~kg} \mathrm{ha}^{-1}\right)$ and four $\mathrm{P}_{2} \mathrm{O}_{5}$ doses (30, 60,90 and $\left.120 \mathrm{~kg} \mathrm{ha}^{-1}\right)$. The experiment did not use doses of 0 (zero) $\mathrm{kg} \mathrm{ha}^{-1}$ of $\mathrm{N}$ or $\mathrm{P}_{2} \mathrm{O}_{5}$, because the soil in the area was very poor in $\mathrm{N}$ and $\mathrm{P}$. At planting, $\mathrm{P}$ doses were applied according to each treatment, besides $1.5 \mathrm{~kg} \mathrm{ha}^{-1}$ of $\mathrm{B}, 1 \mathrm{~kg} \mathrm{ha}^{-1}$ of $\mathrm{Zn}$ and $0.5 \mathrm{~kg} \mathrm{ha}^{-1}$ of $\mathrm{Cu}$. For $\mathrm{N}$ doses, $20 \%$ of the dose was applied at planting in the form of urea and the rest was divided into two top-dressing fertilizations at 30 and 50 days after emergence (DAE), using ammonium sulfate. $75 \mathrm{~kg} \mathrm{ha}^{-1}$ of $\mathrm{K}_{2} \mathrm{O}$ were applied, $50 \%$ of the dose at planting and the rest at 30 DAE.

Irrigations were performed using a drip system, with pressure-compensating drippers, and the interval between irrigations was based on crop Kc and potential evapotranspiration. Weeds were controlled by two manual weedings until $35 \mathrm{DAE}$. At $47 \mathrm{DAE}, 12$ soil samples were collected in the $0-20 \mathrm{~cm}$ layer (Oliveira et al., 2007) in the evaluation area of each plot, to determine $\mathrm{P}$ contents (EMBRAPA, 1997). At 67 DAE, leaves from the upper middle third of 14 plants were collected in the evaluation area of each plot (Malavolta et al., 1997) for the analysis of $\mathrm{N}$ and $\mathrm{P}$ contents, according to Tedesco et al. (1997).

At the end of the experiment, at $118 \mathrm{DAE}, 10$ plants were randomly selected in the evaluation area of each plot and analyzed for: plant height (distance from soil to capitulum insertion), stem diameter (5 $\mathrm{cm}$ away from the soil) and capitulum diameter. Plants in the evaluation area of each plot were counted and their capitulum were cut and placed in cloth bags to dry in the sun. Capitulum grains of each plot were manually separated and weighed to obtain grain yield and 1000-grain weight.

A multiple linear regression model was fitted to the means of each treatment and, after selecting the model with best fit, response surfaces were constructed using the program Statistica 6.0 for Windows.

The economic analysis considered the mean price of fertilizers and sunflower bag in the region. Grain yields were estimated for each combination of $\mathrm{N}$ and $\mathrm{P}$ doses using the fitted multiple regression model, calculating gross revenue, expenditure with fertilizers and net revenue for each combination of $\mathrm{N}$ and $\mathrm{P}$ doses.

\section{Results AND Discussion}

The effects of $\mathrm{N}$ and $\mathrm{P}_{2} \mathrm{O}_{5}$ doses on sunflower growth characteristics, despite being significant, were of small magnitude. The interactions between $\mathrm{N}$ and $\mathrm{P}_{2} \mathrm{O}_{5}$ doses were not significant. Plant height was higher with the increment in $\mathrm{N}$ and $\mathrm{P}_{2} \mathrm{O}_{5}$ doses up to the maximum value of $1.86 \mathrm{~m}$, corresponding to the doses of $99 \mathrm{~kg} \mathrm{ha}^{-1}$ of $\mathrm{N}+99 \mathrm{~kg} \mathrm{ha}^{-1}$ of $\mathrm{P}_{2} \mathrm{O}_{5}\left(\mathrm{Y}=1.40+0.00325^{* *} \mathrm{~N}-0.00001646^{*} \mathrm{~N}^{2}+0.006023^{* *} \mathrm{P}-\right.$ $0.00003035^{* *} \mathrm{P}^{2}, \mathrm{R}^{2}=0.89$ - Figure 1$)$.

Sunflower height may exhibit wide variation, reflecting the differences between cultivars regarding plant size. Tomich et al. (2003) found plant height of $2.05 \mathrm{~m}$, whereas Biscaro et al. (2008) estimated that the $\mathrm{N}$ dose of $73 \mathrm{~kg} \mathrm{ha}^{-1}$ was associated with plant height of $1.15 \mathrm{~m}$, which is inferior to the value found in the present study for a similar $\mathrm{N}$ dose (Figure 1). On the other hand, Schwerz et al. (2016) did not observe effect of $\mathrm{N}$ fertilization on sunflower height. 


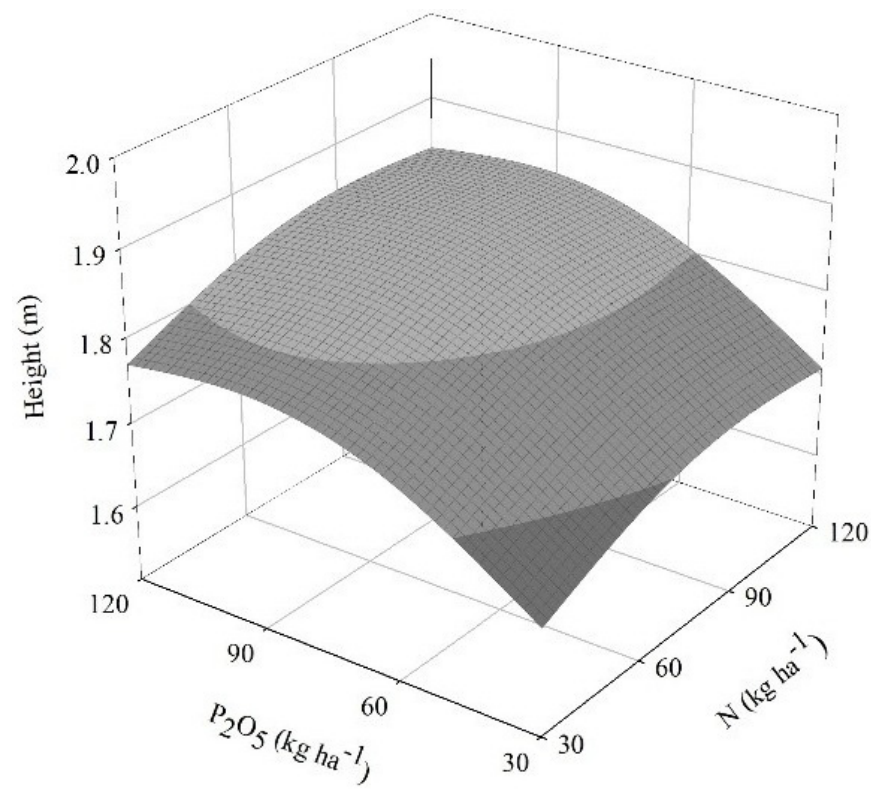

Figure 1. Response surface for sunflower height as a function of $\mathrm{N}$ and $\mathrm{P}_{2} \mathrm{O}_{5}$ doses applied in the soil

The increment in $\mathrm{N}$ and $\mathrm{P}_{2} \mathrm{O}_{5}$ doses increased sunflower stem diameter up to the maximum value of $2.40 \mathrm{~cm}$, corresponding to the doses of $90 \mathrm{~kg} \mathrm{ha}^{-1}$ of $\mathrm{N}+99 \mathrm{~kg} \mathrm{ha}^{-1}$ of $\mathrm{P}_{2} \mathrm{O}_{5}\left(\mathrm{Y}=1.43+0.009858^{* *} \mathrm{~N}-0.00005486^{* *} \mathrm{~N}^{2}+0.01049^{* *} \mathrm{P}\right.$ $-0.00005278^{* *} \mathrm{P}^{2}, \mathrm{R}^{2}=0.84$ - Figure $\left.2 \mathrm{~A}\right)$. Highest value of capitulum diameter $(16.45 \mathrm{~cm})$ was estimated for doses of $95 \mathrm{~kg} \mathrm{ha}^{-1}$ of $\mathrm{N}+120 \mathrm{~kg} \mathrm{ha}^{-1}$ of $\mathrm{P}_{2} \mathrm{O}_{5}\left(\mathrm{Y}=12.68+0.04768^{* *} \mathrm{~N}-\right.$ $0.0002509^{*} \mathrm{~N}^{2}+0.01261^{* *} \mathrm{P}, \mathrm{R}^{2}=0.67$ - Figure $\left.2 \mathrm{~B}\right)$.

Biscaro et al. (2008) observed maximum stem diameter of $1.84 \mathrm{~cm}$ at the $\mathrm{N}$ dose of $48 \mathrm{~kg} \mathrm{ha}^{-1}$ and maximum capitulum diameter of $11.9 \mathrm{~cm}$ at $\mathrm{N}$ dose of $45 \mathrm{~kg} \mathrm{ha}^{-1}$. Freitas et al. (2012) found capitulum diameter of $15.38 \mathrm{~cm}$ with $\mathrm{N}$ application of $75 \mathrm{~kg} \mathrm{ha}^{-1}$. These differences in the results may be attributed to the genetic differences between the cultivars.

There was no significant effect of $\mathrm{N}$ and $\mathrm{P}_{2} \mathrm{O}_{5}$ doses on leaf $\mathrm{N}$ contents, which ranged from $28.2 \mathrm{~g} \mathrm{~kg}^{-1}\left(30 \mathrm{~kg} \mathrm{ha}^{-1}\right.$ of $\mathrm{N}+30 \mathrm{~kg} \mathrm{ha}^{-1}$ of $\left.\mathrm{P}_{2} \mathrm{O}_{5}\right)$ to $36.1 \mathrm{~g} \mathrm{~kg}^{-1}\left(120 \mathrm{~kg} \mathrm{ha}^{-1}\right.$ of $\mathrm{N}+60 \mathrm{~kg} \mathrm{ha}^{-1}$ of $\left.\mathrm{P}_{2} \mathrm{O}_{5}\right)$. Thus, it can be considered that the critical leaf $\mathrm{N}$ content of $28.2 \mathrm{~g} \mathrm{~kg}^{-1}$ is lower than that described by Malavolta et al. (1997) as adequate for sunflower, which ranges from 33 to $35 \mathrm{~g} \mathrm{~kg}^{-1}$.

The lack of response of leaf $\mathrm{N}$ content to the increase in $\mathrm{N}$ and $\mathrm{P}_{2} \mathrm{O}_{5}$ doses can be explained by the effect of dilution of leaf $\mathrm{N}$ content due to the greater plant growth in response to the increase in the applied doses of $\mathrm{N}$ and $\mathrm{P}_{2} \mathrm{O}_{5}$ (Figures 1 and 2). Ribeirinho et al. (2012), applying $10 \mathrm{~kg} \mathrm{ha}^{-1}$ of $\mathrm{N}$, observed leaf $\mathrm{N}$ contents in sunflower plants of the order of $36.84 \mathrm{~g} \mathrm{~kg}^{-1}$, higher than those observed in the present study.

As expected, leaf $\mathrm{P}$ contents increased as a function of the $\mathrm{P}_{2} \mathrm{O}_{5}$ doses, but decreased with the increment in $\mathrm{N}$ doses, possibly due to the dilution effect (Figure 3A). Therefore, maximum leaf $\mathrm{P}$ content $\left(3.1 \mathrm{~g} \mathrm{~kg}^{-1}\right)$ was estimated in the combination between the highest $\mathrm{P}_{2} \mathrm{O}_{5}$ dose $\left(120 \mathrm{~kg} \mathrm{ha}^{-1}\right)$ and lowest $\mathrm{N}$ dose $\left(30 \mathrm{~kg} \mathrm{ha}^{-1}\right)\left(\mathrm{Y}=2.89-0.003993^{* *} \mathrm{~N}+\right.$ $\left.0.002631^{* *} \mathrm{P}, \mathrm{R}^{2}=0.60\right)$.

Leaf $\mathrm{P}$ contents in the present study, even the maximum estimated $\mathrm{P}$ content $\left(3.1 \mathrm{~g} \mathrm{~kg}^{-1}\right)$, were below the $\mathrm{P}$ range from 4.0 to $7.0 \mathrm{~g} \mathrm{~kg}^{-1}$ considered as ideal by Malavolta et al. (1997)
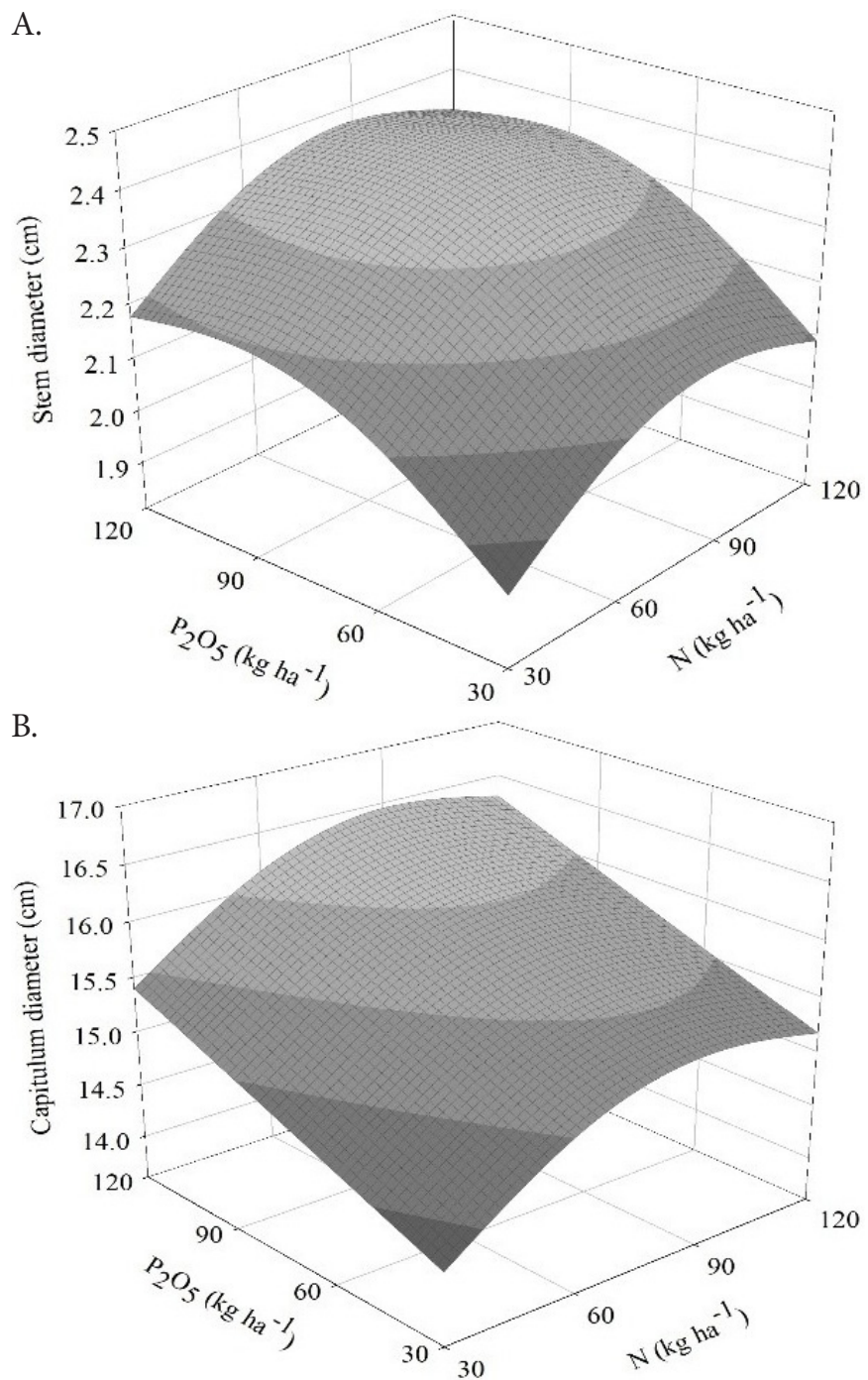

Figure 2. Response surface for stem diameter (A) and capitulum diameter (B) of sunflower plants as a function of $\mathrm{N}$ and $\mathrm{P}_{2} \mathrm{O}_{5}$ doses applied in the soil

for sunflower. However, Deibert \& Utter (1989) indicated P contents between 2.2 and $5.2 \mathrm{~g} \mathrm{~kg}^{-1}$ as adequate for sunflower leaves in early flowering. Available $\mathrm{P}$ content in the soil sharply increased with the increment in the $\mathrm{P}_{2} \mathrm{O}_{5}$ dose applied to the soil, with a slight reduction as $\mathrm{N}$ dose increased ( $\mathrm{Y}=3.19-$ $0.01531^{\star} \mathrm{N}+0.1337^{\star *} \mathrm{P}, \mathrm{R}^{2}=0.81$ - Figure $\left.3 \mathrm{~B}\right)$.

Both 1000-grain weight and grain yield increased with the increment in the $\mathrm{N}$ and $\mathrm{P}_{2} \mathrm{O}_{5}$ doses (Figure 4). It is estimated that the highest 1000-grain weight is obtained with the application of maximum doses $\left(120 \mathrm{~kg} \mathrm{ha}^{-1}\right)$ of $\mathrm{N}$ and $\mathrm{P}_{2} \mathrm{O}_{5}$, since the plant response to these nutrients was linear $(\mathrm{Y}=$ $53.66+0.03711^{\star \star} \mathrm{N}+0.04864^{\star \star} \mathrm{P} ; \mathrm{R}^{2}=0.78$ - Figure $\left.4 \mathrm{~A}\right)$. Silva et al. (2011) observed increments of approximately $9.5 \%$ in 1000-grain weight with the application of $70 \mathrm{~kg} \mathrm{ha}^{-1}$ of phosphate fertilizer, compared with the control, evidencing the importance of $\mathrm{P}$ in the production and quality of sunflower seeds. Maia Filho et al. (2013) found 1000-grain weight varying from 18 to $30.70 \mathrm{~g}$ with $\mathrm{N}$ and $\mathrm{P}$ fertilization at doses of 40 and $70 \mathrm{~kg} \mathrm{ha}^{-1}$, respectively, which are much lower than those observed in the present study, $63.94 \mathrm{~g}$.

Grain yield reached $3,026 \mathrm{~kg} \mathrm{ha}^{-1}$, with application of 120 $\mathrm{kg} \mathrm{ha}^{-1}$ of $\mathrm{N}$ and $117 \mathrm{~kg} \mathrm{ha}^{-1}$ of $\mathrm{P}_{2} \mathrm{O}_{5}, \mathrm{Y}=2010.2+3.6115^{\star \star} \mathrm{N}$ $+9.9484^{* *} \mathrm{P}-0.04245^{\star} \mathrm{P}^{2} \mathrm{R}^{2}=0.83$ (Figure $4 \mathrm{~B}$ ). This yield is 

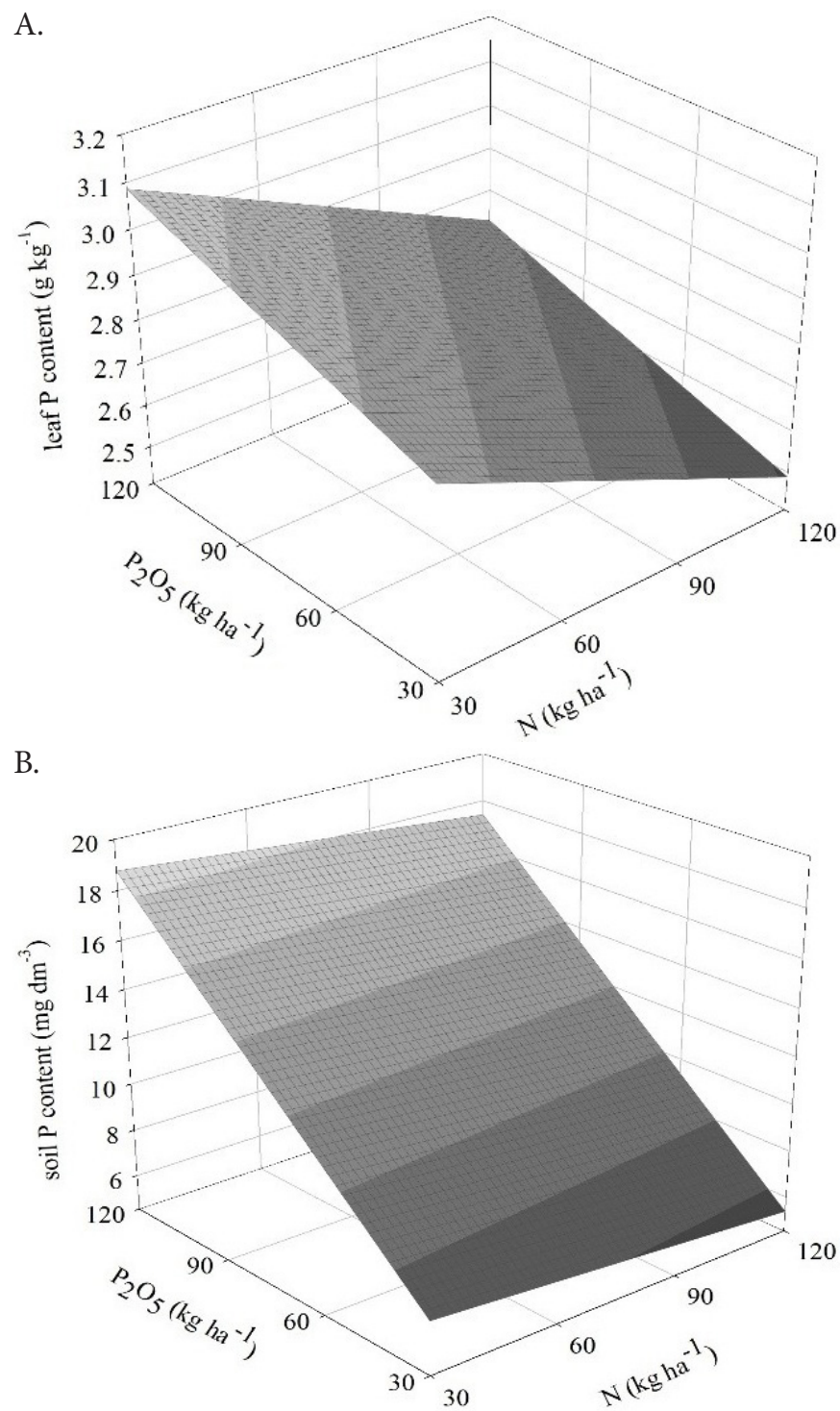

Figure 3. Response surfaces for sunflower leaf $P$ content $(A)$ and soil $\mathrm{P}$ content (B), as a function of $\mathrm{N}$ and $\mathrm{P}_{2} \mathrm{O}_{5}$ doses applied to the soil

above that observed by Nascimento et al. (2013), 2,210 kg ha-1, who cultivated sunflower fertilized with $20 \mathrm{~kg} \mathrm{ha}^{-1}$ of $\mathrm{N}$ and 70 $\mathrm{kg} \mathrm{ha}^{-1}$ of $\mathrm{P}_{2} \mathrm{O}_{5}$. As for the other variables analyzed in the plant (Figures 1 and 2), the magnitude of the positive effects of $\mathrm{N}$ and $\mathrm{P}_{2} \mathrm{O}_{5}$ doses on grain yield was not very high. However, that does not mean the sunflower crop does not respond to $\mathrm{N}$ and $P$ fertilizations. Actually, the responses were small because the doses varied from 30 to $120 \mathrm{~kg} \mathrm{ha}^{-1}$, without an absolute control with no fertilization. If the doses varied from 0 to $120 \mathrm{~kg}$ ha ${ }^{1}$, the magnitudes of the responses would probably be higher, especially for the interval from 0 to $30 \mathrm{~kg} \mathrm{ha}^{-1}$ of $\mathrm{N}$ and $\mathrm{P}_{2} \mathrm{O}_{5}$, due to the very low contents of available $\mathrm{P}$ and organic matter in the soil of the experimental area. In the study of Eltz et al. (2010), $\mathrm{P}_{2} \mathrm{O}_{5}$ doses between 40 and $80 \mathrm{~kg} \mathrm{ha}^{-1}$ were sufficient to reach sunflower grain yield of $2,000 \mathrm{~kg} \mathrm{ha}^{-1}$, whereas Ivanoff et al. (2010) observed yield of $1,639 \mathrm{~kg} \mathrm{ha}^{-1}$ with $\mathrm{N}$ fertilization of $60 \mathrm{~kg} \mathrm{ha}^{-1}$, split into $30 \%$ at planting and $70 \%$ as top-dressing.

In Minas Gerais, the recommendation of phosphate fertilization varies from 30 to $70 \mathrm{~kg} \mathrm{ha}^{-1}$ of $\mathrm{P}_{2} \mathrm{O}_{5}$ according to soil $\mathrm{P}$ content, and $60 \mathrm{~kg} \mathrm{ha}^{-1}$ of $\mathrm{N}$ should be split into $1 / 3$ at planting and 2/3 as top-dressing (CFSEMG, 1999).
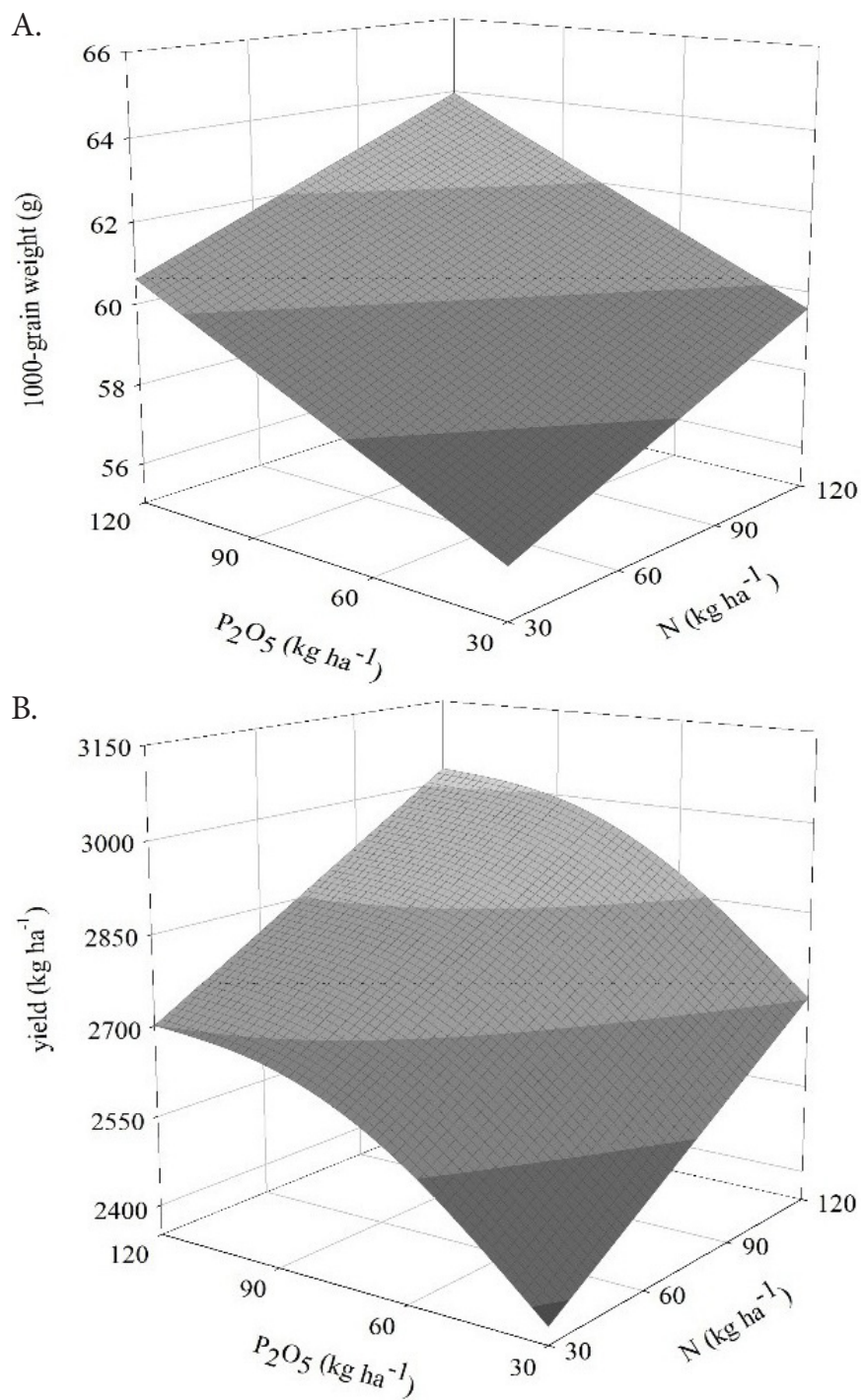

Figure 4. Response surfaces for 1000-grain weight (A) and yield (B) of sunflower as a function of $\mathrm{N}$ and $\mathrm{P}_{2} \mathrm{O}_{5}$ doses applied to the soil

These $\mathrm{N}$ and $\mathrm{P}_{2} \mathrm{O}_{5}$ doses recommended for the sunflower crop corresponded to approximately half the doses estimated for the highest yields (Figure 2B). Attributing the value of $30 \mathrm{~kg} \mathrm{ha}^{-1}$ for $\mathrm{N}$ and $\mathrm{P}_{2} \mathrm{O}_{5}$ doses in the production function (Figure 4B) leads to grain yield of $2,378 \mathrm{~kg} \mathrm{ha}^{-1}$ (Table 1), which corresponds to $78 \%$ of the maximum production. Therefore, the reduction in $\mathrm{N}$ and $\mathrm{P}_{2} \mathrm{O}_{5}$ doses from 120 to $30 \mathrm{~kg} \mathrm{ha}^{-1}$ would reduce grain yield by $648 \mathrm{~kg} \mathrm{ha}^{-1}$, but on the other hand there would be an increment of $\mathrm{R} \$ 176.00$ in net revenue (Table 1).

When doses of $30 \mathrm{~kg} \mathrm{ha}^{-1}$ of $\mathrm{N}$ and $30 \mathrm{~kg} \mathrm{ha}^{-1}$ of $\mathrm{P}_{2} \mathrm{O}_{5}$ were substituted in the regression equations presented in Figure 3 , the estimated critical contents of $\mathrm{P}$ in the plant and in the soil were $2.84 \mathrm{~g} \mathrm{~kg}^{-1}$ and $6.75 \mathrm{mg} \mathrm{dm}^{-3}$, respectively. These values can be used in the nutritional diagnosis of sunflower in areas with alkaline soils, and guide the recommendations of phosphate fertilization based on soil analysis.

Other field studies are necessary, including in different classes of soils that occur in the region, to adjust the recommendations of fertilization for the crop and the identification of critical contents of $\mathrm{N}$ and $\mathrm{P}$ in the plant and 
Table 1. Gross revenue, expenditure with fertilizers and net revenue of the sunflower crop as a function of $\mathrm{N}$ and $\mathrm{P}_{2} \mathrm{O}_{5}$ doses applied to alkaline soil at the Apodi Plateau, RN, Brazil

\begin{tabular}{|c|c|c|c|c|c|}
\hline $\begin{array}{c}\mathrm{N} \\
\text { dose }\end{array}$ & $\begin{array}{l}\mathrm{P}_{2} \mathrm{O}_{5} \\
\text { dose }\end{array}$ & $\begin{array}{c}\text { Estimated } \\
\text { yield }^{1}\end{array}$ & $\begin{array}{l}\text { Gross } \\
\text { revenue }\end{array}$ & $\begin{array}{c}\text { Expenditure } \\
\text { with fertilizers }\end{array}$ & $\begin{array}{c}\text { Net } \\
\text { revenue }\end{array}$ \\
\hline \multicolumn{3}{|c|}{$\mathrm{kg} \mathrm{ha}^{-1}$} & \multicolumn{3}{|c|}{$\mathrm{R} \$$} \\
\hline 30 & 30 & 2,378 & 1,070 & 155 & 914 \\
\hline 30 & 60 & 2,562 & 1,153 & 231 & 921 \\
\hline 30 & 90 & 2,670 & 1,201 & 306 & 894 \\
\hline 30 & 120 & 2,701 & 1,215 & 382 & 832 \\
\hline 60 & 30 & 2,487 & 1,119 & 235 & 883 \\
\hline 60 & 60 & 2,670 & 1,201 & 311 & 890 \\
\hline 60 & 90 & 2,778 & 1,250 & 387 & 863 \\
\hline 60 & 120 & 2,809 & 1,264 & 462 & 801 \\
\hline 90 & 30 & 2,595 & 1,167 & 315 & 852 \\
\hline 90 & 60 & 2,779 & 1,250 & 391 & 859 \\
\hline 90 & 90 & 2,886 & 1,299 & 467 & 831 \\
\hline 90 & 120 & 2,917 & 1,312 & 542 & 770 \\
\hline 120 & 30 & 2,703 & 1,216 & 396 & 820 \\
\hline 120 & 60 & 2,887 & 1,299 & 471 & 827 \\
\hline 120 & 90 & 2,995 & 1,347 & 547 & 800 \\
\hline 120 & 120 & 3,026 & 1,361 & 622 & 738 \\
\hline
\end{tabular}

Yield estimated by the multiple linear regression model

in the soil. Despite that, the obtained results indicate that the recommendation of fertilization with doses of $30 \mathrm{~kg} \mathrm{ha}^{-1}$ of $\mathrm{N}$ $+30 \mathrm{~kg} \mathrm{ha}^{-1}$ of $\mathrm{P}_{2} \mathrm{O}_{5}$ can be adopted for sunflower cultivation in the Apodi Plateau region.

\section{Conclusions}

1. The doses of $30 \mathrm{~kg} \mathrm{ha}^{-1}$ of $\mathrm{N}+30 \mathrm{~kg} \mathrm{ha}^{-1}$ of $\mathrm{P}_{2} \mathrm{O}_{5}$ are economically viable for the production of sunflower grains in alkaline Haplic Cambisol at the Apodi Plateau.

2. Critical levels for the crop are $28.2 \mathrm{~g} \mathrm{~kg}^{-1}$ for leaf $\mathrm{N}$ content, $2.84 \mathrm{~g} \mathrm{~kg}^{-1}$ for leaf $\mathrm{P}$ content, and $6.75 \mathrm{mg} \mathrm{dm}^{-3}$ for available $\mathrm{P}$ content in the soil extracted by Mehlich-1.

\section{Literature Cited}

Alves, L. S.; Torres Junior, C. V.; Fernandes, M. S.; Santos, A. M. dos; Souza, S. R. de. Soluble fractions and kinetics parameters of nitrate and ammonium uptake in sunflower ("Neon" Hybrid). Revista Ciência Agronômica, v.47, p.13-21, 2016. https://doi. org/10.5935/1806-6690.20160002

Bezerra, F. M. L.; Freitas, C. A. de S.; Silva, A. R. A. da; Mota, S. de B.; Aquino, B. F. de. Irrigation with domestic treated sewage and nitrogen fertilizing in sunflower cultivation. Engenharia Agrícola, v.34, p.1186-1200, 2014. https://doi.org/10.1590/S010069162014000600014

Biscaro, G. A.; Machado, J. R.; Tosta, M. da S.; Mendonça, V.; Soratto, R. P.; Carvalho, L. A. de. Adubação nitrogenada em cobertura no girassol irrigado nas condições de Cassilândia-MS. Ciência e Agrotecnologia, v.32, p.1366-1373, 2008. https://doi.org/10.1590/ S1413-70542008000500002

Campos, V. B.; Chaves, L. H. G.; Guerra, H. O. C. Adubação com NPK e irrigação do girassol em Luvissolo: Comportamento vegetativo. Revista Ambiente \& Água, v.10, p.221-233, 2015. http://dx.doi.org/10.4136/ambi-agua.1482

CFSEMG - Comissão de Fertilidade do Solo do Estado de Minas Gerais. Recomendações para o uso de corretivos e fertilizantes em Minas Gerais. 5.ap. Viçosa: CFSEMG, 1999. 359p.
CONAB - Companhia Nacional de Abastecimento. Acompanhamento da safra brasileira de grãos. v.4 - Safra 2015/16 - Quarto levantamento, Brasília, DF: Conab, 2016. 154p. Disponível em: <http://www.conab.gov.br/OlalaCMS/uploads/ arquivos/15_12_23_17_48_39_girassol_-_conjuntura_mensal_-novembro_de_2015_01.pdf>. Acesso em: 15 Jan. 2017.

Deibert, E. J.; Utter, R. A. Sunflower growth and nutrient uptake: Response to tillage system, hybrid maturity and weed control method. Soil Science Society of America Journal, v.53, p.133-138, 1989. https://doi.org/10.2136/sssaj1989.03615995005300010025x

Eltz, F. L. F.; Villalba, E. H.; Lovato, T. Adubação fosfatada para girassol sob sistema plantio direto no Paraguai. Bragantia, v.69, p.899-904, 2010. https://doi.org/10.1590/S0006-87052010000400016

EMBRAPA - Empresa Brasileira de Pesquisa Agropecuária. Manual de métodos de análise de solo. Rio de Janeiro: Embrapa Solos, 1997. 212p.

Freitas, C. A. S. de; Silva, A. R. A. da; Bezerra, F. M. L.; Andrade, R. R. de; Mota, F. S. B.; Aquino, B. F. de. Crescimento da cultura do girassol irrigado com diferentes tipos de água e adubação nitrogenada. Revista Brasileira de Engenharia Agrícola e Ambiental, v.16, p.1031-1039, 2012. https://doi.org/10.1590/ S1415-43662012001000001

Ivanoff, M. E. A.; Uchôa, S. C. P.; Alves, J. M. A.; Smiderle, O. J.; Sediyama, T. Formas de aplicação de nitrogênio em três cultivares de girassol na savana de Roraima. Revista Ciência Agronômica, v.41, p.319-325, 2010. https://doi.org/10.1590/ S1806-66902010000300001

Leite, R. M. V. B. de C.; Castro, C. de; Brighenti, A. M.; Oliveira, F. A. de; Carvalho, C. G. P. de; Oliveira, A. C. B. de. Indicações para o cultivo de girassol nos estados do Rio Grande do Sul, Paraná, Mato Grosso do Sul, Mato Grosso, Goiás e Roraima. Londrina: Embrapa Soja, 2007. 4p. Comunicado Técnico, 78

Lemos, M. do S. da S.; Curi, N.; Marques, J. J. G. de S. e M.; Ernesto Sobrinho, F. Evaluation of characteristics of Cambisols derived from limestone in low tablelands in northeastern Brazil: Implications for management. Revista Pesquisa Agropecuária Brasileira, v.32, p.825-834, 1997.

Maia Filho, F. das C. F.; Mesquita, E. F. de; Guerra, H. O. C.; Moura, M. F.; Chaves, L. H. G. Effect of cattle manure on sunflower production and water use in two types of soil. Revista Ceres, v.60, p.397-405, 2013. https://doi.org/10.1590/S0034-737X2013000300013

Malavolta, E.; Vitti, G. C.; Oliveira, S. A. Avaliação do estado nutricional das plantas. 2.ed. Piracicaba: Associação Brasileira para Pesquisa da Potassa e do Fosfato, 1997. 319p.

Mota, J. C. A.; Assis Júnior, R. N.; Amaro Filho, J.; Romero, R. E.; Mota, F. O. B.; Libardi, P. L. Atributos mineralógicos de três solos explorados com a cultura do melão na Chapada do Apodi - RN. Revista Brasileira de Ciência do Solo, v.31, p.445-454, 2007. https://doi.org/10.1590/S0100-06832007000300004

Nascimento, A. L.; Sampaio, R. A.; Fernandes, L. A.; Zuba Junio, G. R.; Carneiro, J. P.; Rodrigues, M. N.; Albuquerque, H. C. de. Yield and nutrition of sunflower fertilized with sewage sludge stabilized by different processes. Revista Ceres, v.60, p.683-689, 2013. https:// doi.org/10.1590/S0034-737X2013000500012

Oliveira, F. H. T. de; Arruda, J. A. de; Silva, I. de F. da; Alves, J. do C. Amostragem para avaliação da fertilidade do solo em função do instrumento de coleta das amostras e de tipos de preparo do solo. Revista Brasileira de Ciência do Solo, v.31, p.973-983, 2007. https://doi.org/10.1590/S0100-06832007000500014 
Ribeirinho, V. S.; Melo, W. J. de; Silva, D. H. da; Figueiredo, L. A.; Melo, G. M. P. de. Fertilidade do solo, estado nutricional e produtividade de girassol, em função da aplicação de lodo de esgoto. Pesquisa Agropecuária Tropical, v.42, p.166-173, 2012. https://doi.org/10.1590/S1983-40632012000200002

SBCS - Sociedade Brasileira de Ciência do Solo. Comissão de Química e Fertilidade do Solo - RS/SC. Manual de adubação e de calagem para os Estados do Rio Grande do Sul e de Santa Catarina. Porto Alegre: SBCS-NRS, 2004. 400p.

Schwerz, F.; Caron, B. O.; Elli, E. F.; Oliveira, D. M. de; Monteiro, G. C.; Souza, V. Q. de. Avaliação do efeito de doses e fontes de nitrogênio sobre variáveis morfológicas, interceptação de radiação e produtividade do girassol. Revista Ceres, v.63, p.380-386, 2016. https://doi.org/10.1590/0034-737X201663030015
Silva, H. P. da; Brandão Júnior, D. da S.; Neves, J. M. G.; Sampaio, R. A.; Duarte, R. F.; Oliveira, A. S. Qualidade de sementes de Helianthus annuus L. em função da adubação fosfatada e da localização na inflorescência. Ciência Rural, v.41, p.1160-1165, 2011. https://doi. org/10.1590/S0103-84782011000700009

Tedesco, M. J.; Gianello, C.; Bissani, C. A.; Bohnen, H.; Volkweiss, S. J. Análises de solo, plantas e outros materiais. 2.ed. Porto Alegre: Universidade Federal do Rio Grande do Sul, 1997. 174p. Boletim Técnico, 5

Tomich, T. R.; Rodrigues, J. A. S.; Gonçalves, L. C.; Tomich, R. G. P.; Carvalho, A. U. Potencial forrageiro de cultivares de girassol produzidos na safrinha para ensilagem. Arquivo Brasileiro de Medicina Veterinária e Zootecnia, v.55, p.756-762, 2003. https:// doi.org/10.1590/S0102-09352003000600013 